\title{
molecules
}

ISSN 1420-3049

www.mdpi.com/journal/molecules

Article

\section{New Bioactive Alkyl Sulfates from Mediterranean Tunicates}

Concetta Imperatore ${ }^{1}$, Anna Aiello ${ }^{1}$, Filomena D’Aniello ${ }^{1}$, Paolo Luciano ${ }^{2}$, Rocco Vitalone ${ }^{1}$, Rosaria Meli ${ }^{3}$, Giuseppina Mattace Raso $^{3}$ and Marialuisa Menna ${ }^{1, *}$

1 The NeaNat Group, Dipartimento di Chimica delle Sostanze Naturali, Università degli Studi di Napoli "Federico II”, Via D. Montesano 49, 80131, Napoli, Italy; E-Mails: cimperat@unina.it (C.I.); aiello@unina.it (A.A.); filomena.daniello@unina.it (F.D.); rocco.vitalone@unina.it (R.V.)

2 C.S.I.A.S. (Centro Servizi Interdipartimentale di Analisi Strumentale), Università degli Studi di Napoli "Federico II", Via D. Montesano 49, 80131, Napoli, Italy; E-Mail: pluciano@unina.it

3 Dipartimento di Farmacologia Sperimentale, Università degli Studi di Napoli "Federico II", Via D. Montesano 49, 80131, Napoli, Italy; E-Mails: rosaria.meli@unina.it (R.M.); giuseppina.mattaceraso@unina.it (G.M.R.)

* Author to whom correspondence should be addressed; E-Mail: mlmenna@unina.it; Tel.: +39-081-678518; Fax: +39-081-678552.

Received: 29 September 2012; in revised form: 22 October 2012 / Accepted: 23 October 2012 / Published: 26 October 2012

\begin{abstract}
Chemical investigation of two species of marine ascidians, Aplidium elegans and Ciona edwardsii, collected in Mediterranean area, led to isolation of a series of alkyl sulfates (compounds 1-5) including three new molecules 1-3. Structures of the new metabolites have been elucidated by spectroscopic analysis. Based on previously reported cytotoxic activity of these type of molecules, compounds 1-3 have been tested for their effects on the growth of two cell lines, J774A.1 (BALB/c murine macrophages) and C6 (rat glioma) in vitro. Compounds $\mathbf{1}$ and $\mathbf{2}$ induced selective concentration-dependent mortality on J774A.1 cells.
\end{abstract}

Keywords: natural products; alkyl sulfate; cytotoxic activity; structure elucidation; ascidians

\section{Introduction}

Ascidians have been an extremely rich source of sulfur-containing molecules which, on the other hand, are quite unusual in marine organisms. A number of sulfides/polysulfides, sulphur heterocycles, 
sulfoxides, and alkyl sulfates have been isolated from marine ascidians [1,2]. In particular, these latter compounds, although occasionally reported from marine source [3-6], have shown to be often present in remarkable amounts in solitary ascidians of the families Ascididae and Pyuridae, as well in colonial Polyclinidae species [7-14]. They often have quite simple structures, mostly of polyketide derivation even though in some frameworks an isoprenoid origin is clearly recognized; almost all the isolated compounds are endowed with cytotoxic and/or antiproliferative activity. In the course of our program on discovery of cytotoxic metabolites from Mediterranean ascidians [15,16], we have analyzed the chemical composition of methanol extracts of two species, Aplidium elegans (Monniot \& Monniot, 1983) and Ciona edwardsii (Roule, 1884), both collected in the Bay of Naples, Italy. This investigation yielded, in addition to the known sulfated terpenoids 4 and 5 [10,14], some analogues, compounds 1 and $\mathbf{2}$ from A. elegans, and compound $\mathbf{3}$ from C. edwardsii (Figure 1). The present paper deals with the isolation and structure elucidation of the three new compounds as well as with their cytotoxic activity measured in vitro on J774 (murine macrophage) and C6 (rat astrocytic glioma) cells.

Figure 1. Structures of compounds 1-5.

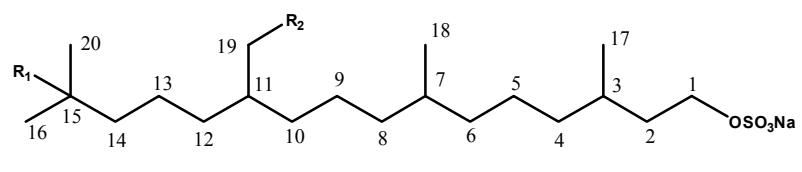

$\begin{array}{lll}1 & \mathrm{R}_{1} & =\mathrm{OH} ; \mathrm{R}_{2}=\mathrm{OSO}_{3} \mathrm{Na} \\ 4 & \mathrm{R}_{1}=\mathrm{H} ; \quad \mathrm{R}_{2}=\mathrm{OSO}_{3} \mathrm{Na}\end{array}$

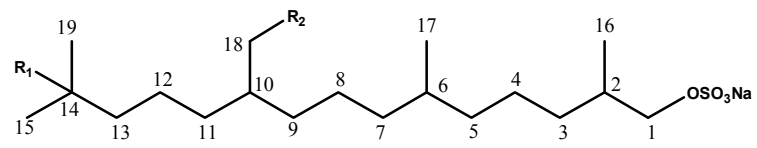

$2 \mathrm{R}_{1}=\mathrm{OH} ; \mathrm{R}_{2}=\mathrm{OSO}_{3} \mathrm{Na}$

$\begin{array}{lll}3 & \mathrm{R}_{1}=\mathrm{H} ; & \mathrm{R}_{2}=\mathrm{OH} \\ \mathbf{5} & \mathrm{R}_{1}=\mathrm{H} ; & \mathrm{R}_{2}=\mathrm{OSO}_{3} \mathrm{Na}\end{array}$

\section{Results and Discussion}

Fresh thawed tissues of both $A$. elegans and C. edwardsii, collected in the bay of Naples, immediately frozen, and kept at $-28{ }^{\circ} \mathrm{C}$ until extraction, were exhaustively extracted with methanol and, subsequently, with chloroform. For each ascidian sample, the extracts were combined and concentrated; the resulting aqueous suspensions were then partitioned between water and butanol. The butanol extract of $A$. elegans was fractionated by MPLC over a reversed phase C-18 column using stepwise elution with aqueous $\mathrm{MeOH}$. The fractions eluted with 50\% aqueous $\mathrm{MeOH}$ were further separated and purified by reversed-phase HPLC eluting with $70 \%$ aqueous $\mathrm{MeOH}$ containing $0.1 \%$ TFA, thus affording compounds $\mathbf{1}$ and $\mathbf{2}$ in the pure state. The butanol extract of $C$. edwardsii was fractionated by reversed-phase MPLC under the same conditions as described for that of A. elegans. Further separation and purification of both fractions eluted with $70 \%$ and $50 \%$ aqueous $\mathrm{MeOH}$ by repeated reversed-phase HPLC yielded compounds 3-5 in the pure state.

A first survey of the 1D NMR spectra $\left(\mathrm{CD}_{3} \mathrm{OD}\right)$ of 1 and the comparison with those of the already known compound $\mathbf{4}$ readily allowed us to hypothesize that $\mathbf{1}$ was the 15 -hydroxy analogous of $\mathbf{4}$. The proton spectrum of $\mathbf{1}$ lacked indeed the signals due to the isopropyl terminus portion of $\mathbf{4}$, whereas it 
contained a quite deshielded methyl signal $(\delta 1.14)$, resonating as a singlet and integrating for six protons. Likewise, the ${ }^{13} \mathrm{C}$-NMR spectrum of 1 contained a quaternary carbon resonance $(\delta 70.8)$ attributable to an oxygen-bearing carbon while the methine signal at $\delta 29.1$ due to C-15 in 4 was absent. Chemical shifts and coupling patterns of the remaining signals of $\mathbf{1}$, assigned by aid of COSY, HSQC, and HMBC experiments were very similar to those of 4. Mass data analysis confirmed the assumption made. ESI mass spectrum (negative ion mode) contained an ion peak at $\mathrm{m} / \mathrm{z} 511$; an intense fragment at $\mathrm{m} / \mathrm{z} 453$ was present and it was interpreted as the result of an $\alpha$ cleavage at $\mathrm{C}-15$. High resolution analysis on the pseudomolecular ion peak gave $m / z 511.1987$, which was consistent with the molecular formula $\mathrm{C}_{20} \mathrm{H}_{40} \mathrm{NaO}_{9} \mathrm{~S}_{2}$ corresponding to $[\mathrm{M}-\mathrm{Na}]^{-}$(calculated value: 511.2006 ). The location of the hydroxyl group at C-15 was unambiguously established through 2D-NMR experiments which allowed us also to assign all the proton and carbon resonances of compound 1 (Table 1). In particular, diagnostic ${ }^{3} J_{\mathrm{C}-\mathrm{H}}$ long-range couplings were observed in the HMBC spectrum between the signal at $\delta 1.14\left(\mathrm{~s}, 6 \mathrm{H}, \mathrm{CH}_{3}-16 / 20\right)$ and both the oxygenated quaternary carbon at $\delta 70.8(\mathrm{C}-15)$ and the methylene carbon at $\delta 44.4(\mathrm{C}-14)$.

Table 1. ${ }^{1} \mathrm{H}$ and ${ }^{13} \mathrm{C}-\mathrm{NMR}$ data of compounds $\mathbf{1}-\mathbf{3}$ in $\mathrm{CD}_{3} \mathrm{OD}$.

\begin{tabular}{|c|c|c|c|c|c|c|}
\hline \multirow[b]{2}{*}{ Pos. } & \multicolumn{2}{|l|}{1} & \multicolumn{2}{|l|}{2} & \multicolumn{2}{|l|}{3} \\
\hline & $\delta_{\mathrm{H}}($ mult., $J$ in $\mathrm{Hz})$ & $\delta_{\mathrm{C}}$ & $\delta_{\mathrm{H}}($ mult., $J$ in $\mathrm{Hz}$ ) & $\delta_{\mathrm{C}}$ & $\delta_{\mathrm{H}}($ mult., $J$ in $\mathrm{Hz}$ ) & $\delta_{\mathrm{C}}$ \\
\hline 1 & $4.02(\mathrm{~m})$ & 66.7 & $\begin{array}{c}3.80\left(\mathrm{H}_{\mathrm{a}}, \mathrm{dd}\right. \\
6.6,9.1)\end{array}$ & 73.2 & $\begin{array}{c}3.79\left(\mathrm{H}_{\mathrm{a}}, \mathrm{dd}\right. \\
6.6-9.4)\end{array}$ & 73.6 \\
\hline & & & $\begin{array}{c}3.88\left(\mathrm{H}_{\mathrm{b}}, \mathrm{dd}\right. \\
6.6,9.1)\end{array}$ & & $\begin{array}{c}3.87\left(\mathrm{H}_{\mathrm{a}}, \mathrm{dd}\right. \\
6.6-9.4)\end{array}$ & \\
\hline 2 & $\begin{array}{c}1.42^{\mathrm{a}}\left(\mathrm{H}_{\mathrm{a}}\right) \\
1.68\end{array}$ & 36.7 & $1.78(\mathrm{~m})$ & 33.5 & $1.79(\mathrm{~m})$ & 34.1 \\
\hline 3 & $\begin{array}{c}1.68\left(\mathrm{~m}, \mathrm{H}_{\mathrm{b}}\right) \\
1.60(\mathrm{~m})\end{array}$ & 29.9 & $\begin{array}{c}1.14(\mathrm{~m}) \\
1.40 \\
1.41^{\mathrm{a}}\end{array}$ & 33.7 & $\begin{array}{c}1.14(\mathrm{~m}) \\
1.43 \\
1.4^{\mathrm{a}}\end{array}$ & 34.3 \\
\hline 4 & $\begin{array}{c}1.10^{\mathrm{a}} \\
1.30^{\mathrm{a}} \\
1.30^{\mathrm{a}}\end{array}$ & 37.6 & $1.33^{\mathrm{a}}$ & 24.5 & $1.32^{\mathrm{a}}$ & 25.1 \\
\hline 5 & $1.30^{\mathrm{a}}$ & 24.6 & $\begin{array}{l}1.10^{\mathrm{a}} \\
1.30 \\
1.30^{\mathrm{a}}\end{array}$ & 37.6 & $\begin{array}{l}1.11^{\mathrm{a}} \\
1.32 \\
1.30^{\mathrm{a}}\end{array}$ & 38.1 \\
\hline 6 & $\begin{array}{c}1.10^{\mathrm{a}}\left(\mathrm{H}_{\mathrm{a}}\right) \\
1.30 \\
1.28^{\mathrm{a}}\left(\mathrm{H}_{\mathrm{b}}\right)\end{array}$ & 37.6 & $1.39^{\mathrm{a}}$ & 33.0 & $1.41^{\mathrm{a}}$ & 33.5 \\
\hline 7 & $1.40^{\mathrm{a}}$ & 33.1 & $\begin{array}{l}1.10^{\mathrm{a}} \\
1.30 \\
1.30^{\mathrm{a}}\end{array}$ & 37.6 & $\begin{array}{l}1.11^{\mathrm{a}} \\
1.32 \\
1.30^{\mathrm{a}}\end{array}$ & 38.1 \\
\hline 8 & $\begin{array}{c}1.09^{\mathrm{a}}\left(\mathrm{H}_{\mathrm{a}}\right) \\
1.28 \\
1.28^{\mathrm{a}}\left(\mathrm{H}_{\mathrm{b}}\right)\end{array}$ & 37.7 & $1.33^{\mathrm{a}}$ & 24.5 & $1.32^{\mathrm{a}}$ & 25.1 \\
\hline 9 & $1.29^{\mathrm{a}}$ & 24.6 & $\begin{array}{l}1.31^{\mathrm{a}} \\
1.36 \\
1.36^{\mathrm{a}}\end{array}$ & 31.7 & $\begin{array}{l}1.23^{\mathrm{a}} \\
1.33^{\mathrm{a}} \\
1.32^{\mathrm{a}}\end{array}$ & 31.9 \\
\hline
\end{tabular}


Table 1. Cont.

\begin{tabular}{ccccccc}
\hline & \multicolumn{1}{c}{$\mathbf{1}$} & \multicolumn{2}{c}{$\mathbf{2}$} \\
\cline { 2 - 6 } Pos. & $\boldsymbol{\delta}_{\mathbf{H}}(\mathbf{m u l t} ., \boldsymbol{J}$ in $\mathbf{H z})$ & $\boldsymbol{\delta}_{\mathbf{C}}$ & $\boldsymbol{\delta}_{\mathbf{H}}(\mathbf{m u l t} ., \boldsymbol{J}$ in $\mathbf{H z})$ & $\boldsymbol{\delta}_{\mathbf{C}}$ & $\boldsymbol{\delta}_{\mathbf{H}}$ (mult., $\boldsymbol{J}$ in $\left.\mathbf{H} \mathbf{z}\right)$ & $\boldsymbol{\delta}_{\mathbf{C}}$ \\
\hline $\mathbf{1 0}$ & $1.30^{\mathrm{a}}$ & 32.0 & $1.66(\mathrm{~m})$ & 38.4 & $1.44(\mathrm{~m})$ & 41.4 \\
& 1.38 & & & & & \\
& $1.38^{\mathrm{a}}$ & & & & & \\
$\mathbf{1 1}$ & $1.65(\mathrm{~m})$ & 38.4 & $1.30^{\mathrm{a}}$ & 31.9 & $1.23^{\mathrm{a}}$ & 31.9 \\
& & & 1.38 & & 1.33 & \\
& & & $1.38^{\mathrm{a}}$ & & $1.32^{\mathrm{a}}$ & \\
$\mathbf{1 2}$ & $1.36^{\mathrm{a}}$ & 31.7 & $1.33^{\mathrm{a}}$ & 24.5 & $1.33^{\mathrm{a}}$ & 25.2 \\
$\mathbf{1 3}$ & $1.30^{\mathrm{a}}$ & 24.6 & $1.42^{\mathrm{a}}$ & 44.4 & $1.19(\mathrm{~m})$ & 40.3 \\
$\mathbf{1 4}$ & $1.42^{\mathrm{a}}$ & 44.4 & - & 70.7 & $1.55(\mathrm{~m})$ & 28.9 \\
$\mathbf{1 5}$ & - & 70.8 & $1.15(\mathrm{~s})$ & 28.3 & $0.89(\mathrm{~d}, 6.4)$ & 22.8 \\
$\mathbf{1 6}$ & $1.14(\mathrm{~s})$ & 28.4 & $0.94(\mathrm{~d}, 6.6)$ & 16.3 & $0.96(\mathrm{~d}, 6.6)$ & 16.9 \\
$\mathbf{1 7}$ & $0.90(\mathrm{~d}, 6.6)$ & 18.9 & $0.86(\mathrm{~d}, 6.6)$ & 19.2 & $0.88(\mathrm{~d}, 6.4)$ & 19.9 \\
$\mathbf{1 8}$ & $0.85(\mathrm{~d}, 6.6)$ & 19.2 & $3.92(\mathrm{~d}, 5.4)$ & 70.8 & $3.44(\mathrm{~d}, 5.4)$ & 65.5 \\
$\mathbf{1 9}$ & $3.91(\mathrm{~d}, 5.4)$ & 70.7 & $1.15(\mathrm{~s})$ & 28.3 & $0.89(\mathrm{~d}, 6.4)$ & 22.8 \\
$\mathbf{2 0}$ & $1.14(\mathrm{~s})$ & 28.4 & - & - & - & - \\
& & & & & 3.86 & \\
\hline
\end{tabular}

${ }^{a}$ Signals overlapped by other resonances.

The negative HRESI mass spectrum (negative ions) of compound $\mathbf{2}$ displayed an ion peak at $\mathrm{m} / \mathrm{z}$ 497.1825 corresponding to [M-Na] ${ }^{-}$(calculated value: $\mathrm{m} / \mathrm{z}$ 497.1849); the molecular formula of 2 was thus established as $\mathrm{C}_{19} \mathrm{H}_{38} \mathrm{NaO}_{9} \mathrm{~S}_{2}$. The ${ }^{1} \mathrm{H}$ - and ${ }^{13} \mathrm{C}$-NMR spectra of compound 2 displayed a close resemblance to those of $\mathbf{1}$, and the observed differences were due to the initial segment of the linear skeleton of both compounds (C1-C3/C16 in 2 and $\mathrm{C} 1-\mathrm{C} 4 / \mathrm{C} 17$ in 1). The multiplet at $\delta 4.02$ due to $2 \mathrm{H}-1$ in compound 1 was replaced by an $\mathrm{ABX}$ system at $\delta 3.80(1 \mathrm{H}, \mathrm{dd}, J=9.1$ and $6.6 \mathrm{~Hz}, \mathrm{H}-1 \mathrm{a})$ and $3.86(1 \mathrm{H}, \mathrm{dd}, J=9.1$ and $6.6 \mathrm{~Hz}, \mathrm{H}-1 \mathrm{~b})$. COSY connectivities, which allowed to delineate the large spin system $\mathrm{C} 1-\mathrm{C} 13$ through $\mathrm{CH}_{3}-16, \mathrm{CH}_{3}-17$ and $\mathrm{CH}_{2}-18$, as well as $\mathrm{HMBC}$ information, clearly evidenced $\mathbf{2}$ as the 1-nor-derivative of $\mathbf{1}$ or, alternatively, the 15-hydroxy analogue of $\mathbf{5}$ (Table 1).

The NMR features $\left(\mathrm{CD}_{3} \mathrm{OD}\right)$ of compound $\mathbf{3}$ appeared almost identical to those of $\mathbf{5}$, except for the chemical shift of the C-18 methylene protons as well as that of the relevant carbon, both showing a significant upfield shift ( $\delta_{\mathrm{H}}$ : 3.94 in 5 vs. 3.44 in 3; $\delta_{\mathrm{C}}$ : 73.9 in $\mathbf{5}$ vs. 65.5 in 3). The negative ion HRESI mass spectrum of $\mathbf{3}$ displayed an ion peak at $\mathrm{m} / \mathrm{z} 379.2522$ which was consistent with the molecular formula $\mathrm{C}_{19} \mathrm{H}_{39} \mathrm{O}_{5} \mathrm{~S}^{-}$, corresponding to [M-Na] ${ }^{-}$(calculated value 379.2513 ). These few data readily allowed us to deduce that $\mathbf{3}$ was the 18-desulfated analogue of $\mathbf{5}$; this conclusion was fully corroborated by 2D NMR spectra analysis which also led to the full assignment of all NMR resonances in 3 (Table 1).

The cytotoxic effect of compounds 1-3 was evaluated on J774A.1 (BALB/c murine macrophages) and C6 (rat glioma) cell lines in vitro. Compounds $\mathbf{1}$ and $\mathbf{2}$ induced a concentration-dependent mortality on J774A.1 (Figure 2) whereas both drugs were inactive on C6 cells, with a $\mathrm{LC}_{50}>$ of $300 \mu \mathrm{M}$ (data not shown). When comparing optical density values of control and treated cells, the cytotoxic effect of compound 1 and $\mathbf{2}$ was significant at the highest concentrations $(p<0.05$, compound 1 at $100 \mu \mathrm{M} ; p<0.05$ and $p<0.01$, compound 2 at 30 and $100 \mu \mathrm{M}$, respectively). The $\mathrm{LC}_{50}$ value of 
compound 2 on J774A. 1 cell line was $45.12 \mu \mathrm{M}$, while that of compound 1 was $>$ of $100 \mu \mathrm{M}$ (Figure 2). The compound 3 was ineffective on both J774A.1 and C6 cells (data not shown). On the basis on these although preliminary data, a sulfate group in R2 and/or a hydroxyl group in R1 seems to be essential for the cytotoxic activity, since they are absent in compound $\mathbf{3}$ which proved inactive. Nevertheless, previous reports showed that compounds $\mathbf{4}$ and $\mathbf{5}$, possessing exclusively the sulfate group in R2, are still active $[10,14]$ therefore, we can conclude that only the latter functionality has an obligatory role for the cytotoxic activity showed by compounds $\mathbf{1}$ and $\mathbf{2}$ against the macrophagic cell line. The slightly different potency of compounds $\mathbf{1}$ and $\mathbf{2}$ could be ascribed to the different length chain; this hypothesis is supported by cytotoxicity data reported in literature for compounds $\mathbf{4}$ and $\mathbf{5}$, where compound $\mathbf{5}$, characterized by a shorter C-chain, resulted more active than its higher analogue $4[10,14]$.

Figure 2. Cytotoxic effect of compounds $\mathbf{1}$ and $\mathbf{2}$ at increasing concentrations on J774A.1 cells. Each per cent value is the mean \pm SEM of three independent experiments.

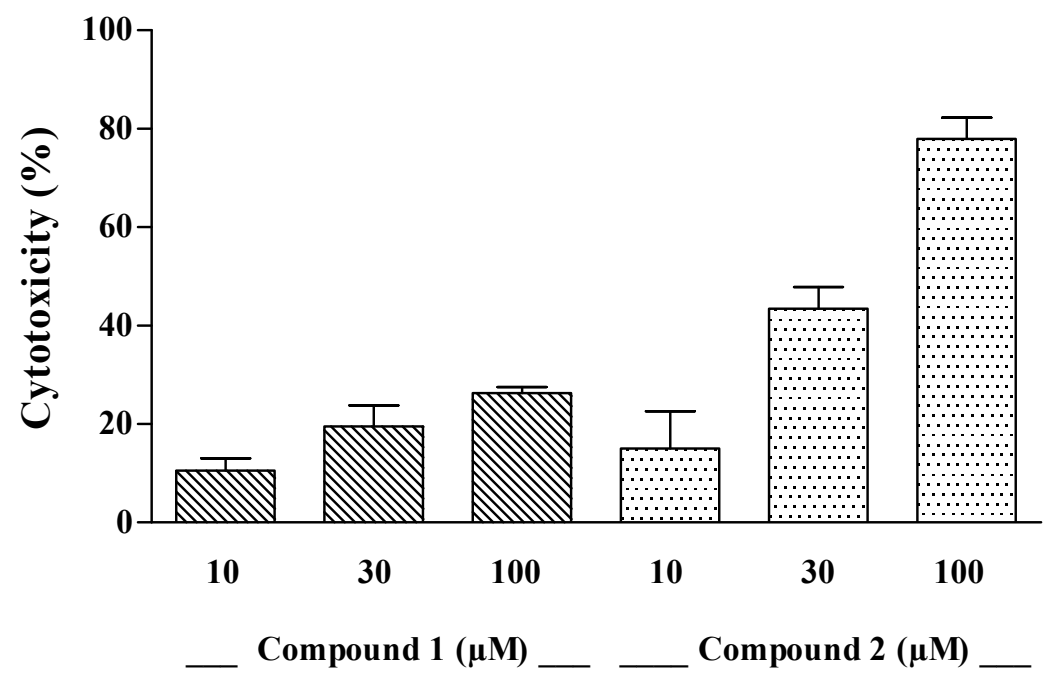

\section{Experimental}

\subsection{General Procedures}

ESI mass spectra were recorded on a Micromass QTOF Micro mass spectrometer in $\mathrm{MeOH}$. The spectra were recorded by infusion into the ESI source using $\mathrm{MeOH}$ as solvent. HRESIMS (negative mode) were performed on a Thermo LTQ Orbitrap XL mass spectrometer. Optical rotations were measured with a Perkin-Elmer 192 polarimeter at $589 \mathrm{~nm}$ using a $10 \mathrm{~cm}$ microcell. ${ }^{1} \mathrm{H}(500 \mathrm{MHz})$ and ${ }^{13} \mathrm{C}(125 \mathrm{MHz}) \mathrm{NMR}$ spectra were recorded on a Varian INOVA spectrometer; chemical shifts were referenced to the residual solvent signal (methanol- $d_{4}$ : $\delta_{\mathrm{H}} 3.31, \delta_{\mathrm{C}} 49.0$ ). Homonuclear ${ }^{1} \mathrm{H}$ connectivities were determined by COSY and TOCSY (mixing time $100 \mathrm{~ms}$ ) experiments. Through-space ${ }^{1} \mathrm{H}$ connectivities were evidenced using a ROESY experiment with a mixing time of $500 \mathrm{~ms}$. Two and three bond ${ }^{1} \mathrm{H}_{-}{ }^{13} \mathrm{C}$ connectivities were determined by gradient 2D HMBC experiments optimized for a $\mathbf{J}_{2,3}$ of $8 \mathrm{~Hz}$. All spectra were acquired at $278 \mathrm{~K}$, and samples were prepared by dissolving compounds $\mathbf{1}-\mathbf{3}$ in $0.5 \mathrm{~mL}$ of methanol- $d_{4}$ (Armar, $100 \% \mathrm{D}$ ). 


\subsection{Extraction and Isolation}

Specimens of $A$. elegans were collected at $-40 \mathrm{~m}$ depth in the autumn of 2003 in the Bay of Naples (Bacoli) and kept frozen until used. The freshly thawed tunicate was homogenized and extracted at room temperature with methanol $(3 \times 1 \mathrm{~L})$ and, subsequently, with chloroform $(3 \times 1 \mathrm{~L})(31.8 \mathrm{~g}$ dry weight of the tunicate after air drying). The combined extracts were concentrated in vacuo to give an aqueous suspension that was subsequently partitioned initially with EtOAc and then with $n-\mathrm{BuOH}$. The butanol-soluble material obtained after evaporation of the solvent ( $4.1 \mathrm{~g}$ of a dark brown oil), was chromatographed on a RP-18 silica gel flash column using a gradient elution $\left(\mathrm{H}_{2} \mathrm{O} / \mathrm{MeOH}\right.$ 9:1 $\rightarrow$ $\mathrm{H}_{2} \mathrm{O} / \mathrm{MeOH} \quad 7: 3 \rightarrow \mathrm{H}_{2} \mathrm{O} / \mathrm{MeOH} \quad 1: 1 \rightarrow \mathrm{H}_{2} \mathrm{O} / \mathrm{MeOH} \quad 3: 7 \rightarrow \mathrm{MeOH} \quad 100 \% \rightarrow \mathrm{MeOH} / \mathrm{CHCl}_{3} \quad 9: 1 \rightarrow$ $\mathrm{MeOH} / \mathrm{CHCl}_{3}$ 7:3 $\rightarrow \mathrm{MeOH} / \mathrm{CHCl}_{3} 1: 1 \rightarrow \mathrm{CHCl}_{3}$ 100\%). The fractions eluted with $\mathrm{H}_{2} \mathrm{O} / \mathrm{MeOH} 1: 1$ were rechromatographed by HPLC on an RP-18 column (Luna, $3 \mu \mathrm{m}, 150 \times 4.60 \mathrm{~mm}$ ), using $\mathrm{H}_{2} \mathrm{O} / \mathrm{MeOH} 7: 3$ containing TFA $0.1 \%$ as the eluent (flow $0.5 \mathrm{~mL} / \mathrm{min}$ ). This separation afforded pure compound 1 (1.2 $\mathrm{mg}$ ) and pure compound $2(1.0 \mathrm{mg})$.

Specimens of $C$. edwardsii were collected at $-75 \mathrm{~m}$ depth in the autumn of 2006 in the Bay of Naples (at $-65 /-75$ meter in Meta di Sorrento Punta Gradelle) and kept frozen until used. The freshly thawed tunicate was homogenized and treated at room temperature with methanol $(3 \times 1 \mathrm{~L})$ and, subsequently, with chloroform $(3 \times 1$ L) (21.9 g dry weight of the tunicate after air drying). The combined extracts were concentrated in vacuo to give an aqueous suspension that was subsequently partitioned initially with EtOAc and then with $n$-BuOH. The butanol-soluble material obtained after evaporation of the solvent (5.4 $\mathrm{g}$ of a dark brown oil), was chromatographed on a RP-18 silica gel flash column using a gradient elution $\left(\mathrm{H}_{2} \mathrm{O} / \mathrm{MeOH}\right.$ 9:1 $\rightarrow \mathrm{H}_{2} \mathrm{O} / \mathrm{MeOH}$ 7:3 $\rightarrow \mathrm{H}_{2} \mathrm{O} / \mathrm{MeOH} 1: 1 \rightarrow \mathrm{H}_{2} \mathrm{O} / \mathrm{MeOH}$ $3: 7 \rightarrow \mathrm{MeOH} 100 \% \rightarrow \mathrm{MeOH} / \mathrm{CHCl}_{3} 9: 1 \rightarrow \mathrm{MeOH} / \mathrm{CHCl}_{3}$ 7:3 $\rightarrow \mathrm{MeOH} / \mathrm{CHCl}_{3}$ 1:1 $\rightarrow \mathrm{CHCl}_{3} 100 \%$ ) The fractions eluted with $\mathrm{H}_{2} \mathrm{O} / \mathrm{MeOH} 3: 7$ were rechromatographed by HPLC on an RP-18 column (Luna, $3 \mu \mathrm{m}, 150 \times 4.60 \mathrm{~mm}$ ), using $\mathrm{H}_{2} \mathrm{O} / \mathrm{MeOH} 72: 28$ containing TFA $0.1 \%$ as the eluent (flow $0.5 \mathrm{~mL} / \mathrm{min}$ ). This separation afforded $2.4 \mathrm{mg}$ of pure compound 3 .

\subsection{Compound 1}

Colorless amorphous solid; $[\alpha]_{\mathrm{D}}{ }^{25}=+2.5\left(c=0.002, \mathrm{CH}_{3} \mathrm{OH}\right)$. ESI-MS (negative ion mode): $m / z=511[\mathrm{M}-\mathrm{Na}]^{-}$; HRESIMS (negative ion mode): $\mathrm{m} / z=511.1987$; the molecular formula $\mathrm{C}_{20} \mathrm{H}_{40} \mathrm{NaO}_{9} \mathrm{~S}_{2}^{-}$requires 511.2006; ${ }^{1} \mathrm{H}-\mathrm{NMR}$ and ${ }^{13} \mathrm{C}-\mathrm{NMR}$ data $\left(\mathrm{CD}_{3} \mathrm{OD}, 500 / 125 \mathrm{MHz}\right)$ are reported in Table 1.

\subsection{Compound 2}

Colorless amorphous solid; $[\alpha]_{\mathrm{D}}{ }^{25}=+3.4\left(c=0.002, \mathrm{CH}_{3} \mathrm{OH}\right)$. ESI-MS (negative ion mode): $m / z=497[\mathrm{M}-\mathrm{Na}]^{-}$; HRESIMS (negative ion mode): $\mathrm{m} / z=497.1825$; the molecular formula

$\mathrm{C}_{19} \mathrm{H}_{38} \mathrm{NaO}_{9} \mathrm{~S}_{2}{ }^{-}$requires $497.1849 ;{ }^{1} \mathrm{H}-\mathrm{NMR}$ and ${ }^{13} \mathrm{C}-\mathrm{NMR}$ data $\left(\mathrm{CD}_{3} \mathrm{OD}, 500 / 125 \mathrm{MHz}\right)$ are reported in Table 1. 


\subsection{Compound $\mathbf{3}$}

Colorless amorphous solid; $[\alpha]_{\mathrm{D}}{ }^{25}=+1.8\left(c=0.002, \mathrm{CH}_{3} \mathrm{OH}\right)$. ESI-MS (negative ion mode): $m / z=379[\mathrm{M}-\mathrm{Na}]^{-}$; ESI-MS (positive ion mode): $\mathrm{m} / z=403[\mathrm{M}+\mathrm{H}]^{+}$; HRESIMS (negative ion mode): $m / z=379.2522$; the molecular formula $\mathrm{C}_{19} \mathrm{H}_{39} \mathrm{O}_{5} \mathrm{~S}^{-}$requires $379.2513 ;{ }^{1} \mathrm{H}-\mathrm{NMR}$ and ${ }^{13} \mathrm{C}-\mathrm{NMR}$ data $\left(\mathrm{CD}_{3} \mathrm{OD}, 500 / 125 \mathrm{MHz}\right)$ are reported in Table 1.

\subsection{Cell Culture}

J774A.1 cell line (BALB/c murine macrophages) was cultured in Dulbecco's modified Eagle's medium (DMEM) supplemented with 4.4\% $\mathrm{NaHCO}_{3}$ (HyClone), penicillin (100 U/mL), streptomycin (100 $\mu \mathrm{g} / \mathrm{mL}), 2 \mathrm{mM}$ glutamine, $25 \mathrm{mM}$ Hepes, $130 \mu \mathrm{g} / \mathrm{mL}$ Na pyruvate and $10 \%$ foetal calf serum (FCS) (Hy Clone). The rat astrocytic glioma C6 cell line was cultured in DMEM supplemented with $10 \%$ FCS, penicillin $(100 \mathrm{U} / \mathrm{mL})$, streptomycin $(100 \mu \mathrm{g} / \mathrm{mL})$, and L-glutamine $2 \mathrm{mM}$. All cells were cultured in plastic tissue culture flasks and kept at $37^{\circ} \mathrm{C}$ under $5 \% \mathrm{CO}_{2}$ atmosphere.

\subsection{Cytotoxicity Assay}

Cytotoxicity studies in both tumour cell lines were performed in a 96-well plate [17,18]. J774A.1 were mechanically scraped, while C6 cells were enzymatically detached. The cells were plated

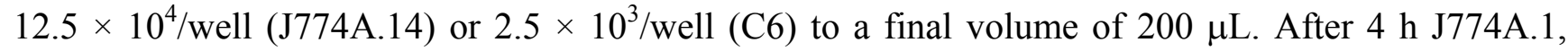
cells were incubated with compounds 1-3 at increasing concentrations $(10-100 \mu \mathrm{M})$ for $22 \mathrm{~h}$; conversely, after 3 days C6 cells were incubated with compounds 1-3 (10-300 $\mu \mathrm{M})$ for $22 \mathrm{~h}$. Then, $25 \mu \mathrm{L}$ of 3-(4,5-dimethylthiazol-2-yl)-2,5-diphenyltetrazolium bromide (MTT, $5 \mathrm{mg} / \mathrm{mL}$ ) was added in each well, $3 \mathrm{~h}$ later the cells were lysated with $100 \mu \mathrm{L}$ of lysis buffer (20\% SDS and 50\% DMF, $\mathrm{pH}$ 4.7). After an incubation of $22 \mathrm{~h}$ at $37{ }^{\circ} \mathrm{C}$ the optical densities $\left(\mathrm{OD}_{620}\right)$ for the serial dilutions of both compounds were compared with the OD of the control wells to assess the citotoxicity [19]. $\mathrm{LC}_{50}$ for each cell line was obtained by statistical computer program.

\subsection{Data Analysis}

Data are reported as mean $\pm \mathrm{SEM}$ values of three independent determinations. All experiments were performed at least three times, each time with three or more independent observations. Statistical analysis was performed by ANOVA test, and multiple comparisons were made by Dunnett test.

\section{Conclusions}

The structures of compounds 1-3, isolated from the Mediterranean ascidians Aplidium elegans and Ciona edwardsii, have been elucidated using mass spectrometry and NMR experiments and their in vitro cytotoxic effects have been evaluated on J774A.1 (BALB/c murine macrophages) and C6 (rat glioma) cell lines. A moderate but selective cytotoxic effect on J774A.1 cell line has been evidenced for compounds $\mathbf{1}$ and $\mathbf{2}$; the inactivity of $\mathbf{3}$, as well as further pharmacological data available in the literature $[10,14]$, indicated that the hydroxyl group does not confer per se cytotoxic activity, 
while the contribution of the sulfate is of pivotal importance. A slight influence of alkyl chain length on the potency of the active compounds has been also evidenced.

\section{Supplementary Materials}

Supplementary materials can be accessed at: http://www.mdpi.com/1420-3049/17/11/12642/s1.

\section{Acknowledgments}

This research was funded by the EU's 7th Framework Programme FP7/2007-2013 under grant agreement $n^{\circ} 229893$ (NatPharma) and by MIUR (PRIN - 2009).

\section{References}

1. Aiello, A.; Menna, M.; Fattorusso, E. Steroids from sponges: Recent reports. Steroids 1999, 64, 687-714.

2. Aiello, A.; Fattorusso, E.; Imperatore, C.; Luciano, P.; Menna, M.; Vitalone R. Aplisulfamines, new sulfoxide-containing metabolites from an Aplidium tunicate: Absolute stereochemistry at chiral sulfur and carbon atoms assigned through an original combination of spectroscopic and computational methods. Mar. Drugs 2012, 10, 51-63.

3. Findlay, J.A.; He, Z.Q.; Calhoun, L.A. Forbesin: A novel sulfated glycolipid from the starfish Asterias forbesi. J. Nat. Prod. 1990, 53, 1015-1018.

4. Findlay, J.A.; Yayli, N.; Calhoun, L.A. Novel sulfated hydrocarbons from the sea cucumber Cucumaria frondosa. J. Nat. Prod. 1991, 54, 302-304.

5. Nakao, Y.; Matsunaga, S.; Fusetani, N. Toxadocial A: A novel thrombin inhibitor from the marine sponge Toxadocia cylindrica. Tetrahedron Lett. 1993, 34, 1511-1514.

6. Roccatagliata, A.J.; Maier, M.S.; Seldes, A.M.; Zea, S.; Duque, C. A new sulfated alkene from the ophiuroid Ophiocoma echinata. J. Nat. Prod. 1997, 60, 285-286.

7. Tsukamoto, S.; Kato, H.; Hirota, H.; Fusetani, N. Antibacterial and antifungal sulfated alkane and alkenes from the hepatopancreas of the ascidian Halocynthia roretzi. J. Nat. Prod. 1994, 57, 1606-1609.

8. Fujita, M.; Nakao, Y.; Matsunaga, S.; Nishikawa, T.; Fusetani, N. Sodium 1-(12hydroxy)octadecanyl sulfate, an MMP2 inhibitor, isolated from a tunicate of the family Polyclinidae. J. Nat. Prod. 2002, 65, 1936-1938.

9. Crispino, A.; De Giulio, A.; De Rosa, S.; De Stefano, S.; Milone, A.; Zavodnik, N. A sulfated normonoterpenoid from the ascidian Polycitor adriaticus. J. Nat. Prod. 1994, 57, 1575-1577.

10. Aiello, A.; Fattorusso, E.; Menna, M.; Carnucccio, R.; D’Acquisto, F. Novel antiproliferative alkyl sulfates from the Mediterranean tunicate Ascidia mentula. Tetrahedron 1997, 53, 5877-5882.

11. Aiello, A.; Fattorusso, E.; Menna, M.; Carnucccio, R.; Iuvone, T. A new antiproliferative sulfated alkene from the Mediterranean tunicate Microcosmus vulgaris. Tetrahedron 1997, 53,11489-11492.

12. De Rosa, S.; Milone, A.; Crispino, A.; Jaklin, A.; De Giulio, A. Absolute configuration of 2,6-dimethylheptyl sulfate and its distribution in Ascidiacea. J. Nat. Prod. 1997, 60, 462-463. 
13. Aiello, A.; Carbonelli, S.; Esposito, G.; Fattorusso, E.; Iuvone, T.; Menna, M. Novel bioactive sulfated alkene and alkanes from the Mediterranean ascidian Halocynthia papillosa. J. Nat. Prod. 2000, 63, 1590-1592.

14. Aiello, A.; Carbonelli, S.; Fattorusso, E.; Iuvone, T.; Menna, M. New bioactive sulfated metabolites from the Mediterranean tunicate Sidnyum turbinatum. J. Nat. Prod. 2001, 64, 219-221.

15. Aiello, A.; Fattorusso, E.; Imperatore, C.; Irace, C.; Luciano, P.; Menna, M.; Santamaria, R.; Vitalone, R. Zorrimidazolone, a bioactive alkaloid from the non-indigenous Mediterranean stolidobranch Polyandrocarpa zorritensis. Mar. Drugs 2011, 9, 1157-1165.

16. Aiello, A.; Fattorusso, E.; Imperatore, C.; Menna, M.; Muller, W.E.G. Iodocionin, a cytotoxic iodinated metabolite from the Mediterranean ascidian Ciona edwardsii. Mar. Drugs 2010, 8, 285-291.

17. Ferrante, M.C.; Mattace Raso, G.; Esposito, E.; Bianco, G.; Iacono, A.; Clausi, M.T.; Amero, P.; Santoro, A.; Simeoli, R.; Autore, G.; et al. Effects of non-dioxin-like polychlorinated biphenyl congeners (PCB 101, PCB 153 and PCB 180) alone or mixed on J774A.1 macrophage cell line: Modification of apoptotic pathway. Toxicol. Lett. 2011, 202, 61-68.

18. Meli, R.; Mattace Raso, G.; Cicala, C.; Esposito, E.; Fiorino, F.; Cirino, G. Thrombin and PAR-1 activating peptide increase iNOS expression in cytokine-stimulated C6 glioma cells. J. Neurochem. 2001, 79, 556-563.

19. Mosmann, T. Rapid colorimetric assay for cellular growth and survival: Application to proliferation and cytotoxicity assays. J. Immunol. Methods 1983, 65, 55-63.

Sample Availability: Samples of the compounds 1-3 are available at the Dipartimento di Chimica delle Sostanze Naturali, Università degli Studi di Napoli "Federico II".

(C) 2012 by the authors; licensee MDPI, Basel, Switzerland. This article is an open access article distributed under the terms and conditions of the Creative Commons Attribution license (http://creativecommons.org/licenses/by/3.0/). 